\title{
Claims by Dual Nationals under Investment Treaties: Are Investors Entitled to Sue Their Own States?
}

\author{
Javier García Olmedo*
}

\begin{abstract}
Nationality plays a vital role in the field of investor-state arbitration. Most investment treaties require that, to benefit from treaty protection, an investor must be a national of the home state. Yet, the determination of nationality for investment treaty purposes can be particularly complex, raising a number of unresolved questions of considerable practical importance. One of these questions is whether investors who hold the nationality of both state parties to an investment treaty (i.e. dual nationals) are entitled to sue their own home state where the treaty is silent on the issue of dual nationality. This contribution contends that, when faced with a claim of this nature, arbitral tribunals should apply the well-established customary rule of dominant and effective nationality, and uphold jurisdiction only if the investor maintains a stronger connection with its home state.
\end{abstract}

\section{INTRODUCTION}

In the field of investor-state arbitration, nationality is decisive for the jurisdiction of arbitral tribunals and the enforcement of the rights granted in investment treaties. These treaties typically contain nationality provisions designating the range of natural and legal persons that qualify for treaty protection. Yet, despite being a condition precedent to enforcing treaty obligations, investment treaties often use sparse wording when defining nationality requirements. They simply require that a company be incorporated in the home state, or that an individual be a national of that state, without further refinement. ${ }^{1}$

Broad nationality requirements increases the risk that, as often occurs in practice, a company based in a third state, or the host state, incorporates a shell company (or

* Javier García Olmedo, Research Fellow, Max Planck Institute Luxembourg for International, European and Regulatory Procedural Law. E-mail: j.garciaolmedo@imprs-sdr.mpi.lu. Valuable comments and criticisms of Professor Matthew Happold, Professor Antonio Marzal Yetano, Dr kate Parlett and Jérémy Faivre are acknowledged. This paper was presented at the 5th Conference of the Postgraduate and Early Professionals/Academics Network of the Society of International Economic Law. The views expressed and the errors or omissions made are the responsibility of the author alone.

1 See, eg, art 1 of the US-Argentina BIT, which defines a protected 'investor' as: 'b) [A]ny kind of corporation, company, association, state enterprise, or other organization, legally constituted under the laws and regulations of a Party; c) [A] natural person who is a national of a Party under its applicable law.'

(C) The Author 2017. Published by Oxford University Press. All rights reserved.

For permissions, please e-mail: journals.permissions@oup.com 
company of convenience) in the home state to gain access to international arbitration. ${ }^{2}$ This type of nationality planning has been criticized recently in the context of the current European Union's policy on the conclusion of free trade agreements with third countries and also stand-alone investment agreements, such as the Comprehensive Economic and Trade Agreement (CETA) and the Transatlantic Trade and Investment Partnership (TTIP).

The European Commission has emphasized that the purpose of investment treaties is to protect nationals of home states, rather than third states. In this context, the European Commission has stated that, to prevent abuse, investment protections should be limited to corporations that have 'substantial business activities' in the territory of the home state. ${ }^{3}$ This requirement can certainly be considered as a useful tool to ensure that corporations that have a real connection with the home state, that is, 'foreign' investors, are protected under the applicable treaty.

However, the often-sparse wording of nationality provisions can also lead individual investors to bring treaty claims that some may consider abusive. This may occur in cases where an investor who holds the nationality of both state parties to an investment treaty (i.e. a dual national) initiates arbitration proceedings against his or her own state. If a dual national brings a treaty claim pursuant to the Convention on the Settlement of Investment Disputes Between States and Nationals of Other States (the ICSID Convention), the claim will automatically fall outside the jurisdiction of the arbitral tribunal. Article 25(2)(a) of the ICSID Convention expressly excludes from its scope of application natural persons who also hold the nationality of the host state. ${ }^{4}$ But what if a dual national brings a claim outside the ICSID Regime and under an investment treaty that does not regulate the issue of dual nationality? Is the absence of a treaty provision on dual nationality a sufficient ground for allowing investors to sue their own state before an international arbitral tribunal?

These questions were raised for the first time in an ongoing arbitration initiated pursuant to the United Nations Commission on International Trade Law (UNCITRAL) Arbitration Rules (1976). This case concerns claims brought under the Spain-Venezuela bilateral investment treaty (the BIT) by two VenezuelanSpanish nationals, Serafín García Armas and Karina García Gruber, against Venezuela. ${ }^{5}$ Neither the UNCITRAL Arbitration Rules nor the BIT regulate the

2 M Feldman, 'Setting Limits on Corporate Nationality Planning in Investment Treaty Arbitration' (2012) 27(2) ICSID Rev, 281.

3 See, eg, European Commission, Online Public Consultation on Investment Protection and Investor-to-State Dispute Settlement (ISDS) in the Transatlantic Trade and Investment Partnership Agreement (TTIP) (2014), 18, < http://trade.ec.europa.eu/doclib/docs/2014/march/tradoc_152280.pdf > accessed 30 May 2017.

4 Art 25(2)(a) of the ICSID Convention provides that: 'National of another Contracting State means: (a) any natural person who had the nationality of a Contracting State other than the State party to the dispute on the date on which the parties consented to submit such dispute to conciliation or arbitration as well as on the date on which the request was registered pursuant to paragraph (3) of Article 28 or paragraph (3) of Article 36, but does not include any person who on either date also had the nationality of the Contracting State party to the dispute.'

5 Serafín García Armas and Karina García Gruber v The Bolivarian Republic of Venezuela, PCA Case No 2013-3, Decision on Jurisdiction, 15 December 2014 (hereinafter: Serafín). To the author's knowledge, this is the first publicly known investment treaty arbitration where a dual national has brought a claim outside the ICSID Convention Regime. The author acted as counsel for Venezuela. The views expressed here are personal to him and do not necessarily reflect the position of either the law firm representing 
issue of dual nationality. The nationality provision in the BIT only requires that natural persons be nationals of the home state, in this case Spain. ${ }^{6}$ Despite this, Venezuela objected to the jurisdiction of the tribunal, arguing that investors who also hold the nationality of the host state fail to qualify as protected foreign investors under the treaty. Venezuela maintained that it had not consented to be sued by its own nationals in an international forum, particularly given that, in the instant case, the individuals maintained a long-standing connection with Venezuela. ${ }^{7}$

Since the BIT contained no rules governing the case of dual nationality, Venezuela relied on other sources of international law to substantiate its objection. It invoked, in particular, the customary rule of 'dominant and effective nationality', which has been widely applied to claims by dual nationals in the context of diplomatic protection. ${ }^{8}$ This rule provides that a home state may exercise diplomatic protection in respect of a dual national only if he or she has stronger connections (personal, economic, political, etc.) with that state. On the facts of the case, however, the claimants had overwhelmingly stronger links with the host state, Venezuela. ${ }^{9}$ Thus, if the test of dominant and effective nationality was to apply, the tribunal would have lacked jurisdiction to hear the dispute.

Venezuela's arguments were unsuccessful. The tribunal decided to accept jurisdiction, ruling that the determination of nationality for the purposes of the BIT should only be assessed by reference to the terms of the treaty itself. ${ }^{10}$ In the tribunal's view, the 'special' regime of investment treaty arbitration, in which investors are allowed to bring direct arbitral claims against states, excluded the application of the diplomatic protection rules of nationality. ${ }^{11}$ The tribunal found that the rules of diplomatic protection developed at a time when it was considered that only states had rights under international law, and that there was no warrant for transferring these rules into a field in which individuals are entitled to enforce their own rights without the intervention of the home state. The tribunal took this view despite the fact that the BIT itself required the application of rules of international law in addition to the terms of the treaty. ${ }^{12}$ It follows, according to this approach, that the absence of an explicit

Venezuela or the Venezuelan government. On 25 April 2017, the Paris Court of Appeal partly upheld a request by Venezuela to set aside the award. The ground for setting aside the award did not however affect the main finding of the Tribunal, namely that the BIT did not exclude claims by dual SpanishVenezuelan nationals. For more information on the setting aside proceedings see: S Perry, 'Decision on Dual Nationals is Partially Set Aside', Global Arbitration Review, 26 April 2017.

6 Art 1 of the Spain-Venezuela BIT defines 'investor' as: 'a) personas físicas que tengan la nacionalidad de una de las Partes Contratantes con arreglo a su legislación y que realicen inversiones en el territorio de la otra Parte Contratante.' 'a) physical persons who are nationals of one of the Contracting States in accordance with its legislation and who make investments in the territory of the other Contracting State.'

7 Serafín (n 5) paras 83-88.

8 ibid paras $107-17$.

9 ibid paras 57-67.

10 ibid paras 159-66.

11 ibid paras $167-75$.

12 See Art XI (4) of the Spain-Venezuela BIT, which provides that: 'The arbitral dispute must be resolved through the application of a) the terms of the present agreement and any other agreements concluded between the States party: b) the rules and principles of international law; and c) the national law of the host State, including its conflict of law rules.' 
treaty provision barring claims by dual nationals was sufficient to allow two Venezuelan investors to sue Venezuela.

Not surprisingly, this decision has created the potential for further treaty claims by investors against their state of nationality, ${ }^{13}$ and has already influenced the position of tribunals currently hearing claims of this nature. ${ }^{14}$ With this in mind, it is still an open question whether a state must submit to the jurisdiction of an investment tribunal in a dispute involving its own national. Formulated differently, should arbitral tribunals have resort to the diplomatic protection rule of dominant and effective nationality when the treaty is silent on the issue of dual nationality?

Most investment tribunals, including the one in Serafin, have found that the rules derived from the interstate system of diplomatic protection (or customary international law) cannot be imported into a field where individuals enjoy ius standi to enforce treaty obligations. This view assumes that international investment law creates a legal framework that completely depart from the diplomatic protection rules of nationality, as if investment treaties were self-contained. The author disagrees with this approach and argues that, while it is true that investment treaty arbitration departs from diplomatic protection in that only the former entitle individuals to bring direct arbitral claims before international tribunals, this does not mean that investment treaties exclude the customary rules of diplomatic protection. It is submitted that the function of investment treaties is to augment (rather than displace) customary law by providing a more efficient mechanism for the protection of alien property. By analysing the nature of diplomatic protection and investment treaty arbitration, this contribution will aim to show that these two systems of dispute resolution share certain fundamental elements that integrate the rules established under them.

For one, it will be shown that the entitlement to diplomatic protection and the operation of investment treaties are both dependent upon the link of nationality between the individual and the home state. This means that individuals claiming under investment treaties and those seeking diplomatic protection are not recognized as international persons independently of their states of nationality.

In addition, it will be suggested that the rights invoked in diplomatic protection and investment treaty arbitration are of a dual nature in the sense that they are jointly held by the individual and the home state. It is difficult to say that the state exercising diplomatic protection on behalf of its national is the only entity in which the corresponding rights vest. After all, the ultimate beneficiary of the claim is the injured individual, whose rights have also been violated. The same is true in the investment treaty regime: investment treaties contain parallel dispute settlement

13 See, eg, Michael Ballantine and Lisa Ballantine v The Dominican Republic, PCA Case No 2016-17, Notice of Arbitration, 11 September 2014; Manuel García Armas et al v The Bolivarian Republic of Venezuela, PCA Case No 2016-08; Sergei Viktorovich Pugachev v the Russian Federation, UNCITRAL, Notice of Arbitration, 21 September 2015 and Dawood Rawat $v$ The Republic of Mauritius, PCA Case No 2016-20, Notice of Arbitration, 9 November 2015.

14 See Cem Cenzig Uzan v Republic of Turkey, SCC Arbitration V 2014/023, Award on Respondent's Bifurcated Preliminary Objection, 20 April 2016 (hereinafter: Uzan v Turkey). As further explained below, in this case, the tribunal relied on Serafin to hold that Mr Uzan, a Turkish national residing in France, was entitled to sue his own state under the Energy Charter Treaty (ECT). 
provisions enabling states to vindicate their own rights before international tribunals. This indicates that the rights granted therein also belong to states.

It is submitted that these common elements reveal that the customary international law of diplomatic protection coexists in parallel to international investment law. In other words, investment treaties are not self-contained instruments, but they must be considered as part of a wider juridical system that integrates rules from other sources of international law. As such, derogation from the diplomatic protection rules of nationality, which would apply as customary international law, should only be accepted to the extent that the state parties have clearly stated such an intention. This is all the more so in cases where the treaty is silent on a particular issue, such as dual nationality.

To substantiate each of these propositions, this contribution will first explore the role of nationality in the fields of diplomatic protection and investment treaty arbitration, including an examination of the customary rule of dominant and effective nationality. It will then examine the question of whose rights are asserted in both the scenario of diplomatic protection and that of direct standing of the individual under investment treaties.

This contribution will conclude that dual nationals should not be permitted to claim against their own state merely on the ground that there is no treaty provision prohibiting them from doing so. In the absence of an express treaty provision to the contrary, arbitral tribunals are empowered, indeed bound, to apply the customary rule of dominant and effective nationality and decline jurisdiction if the investor maintains stronger links with the host state.

\section{THE ROLE OF NATIONALITY IN DIPLOMATIC PROTECTION AND INVESTMENT TREATY ARBITRATION}

In its landmark decision in Nottebohm, the International Court of Justice (ICJ) defined nationality as:

[A] legal bond having as its basis a social fact of attachment, a genuine connection of existence, interests and sentiments, together with the existence of reciprocal rights and duties. It may be said to constitute the juridical expression of the fact that the individual upon whom it is conferred, either directly by the law or as the result of an act of the authorities, is in fact more closely connected with the population of the State conferring nationality than with that of any other State. ${ }^{15}$

The court made this statement after restating the rule that each state has autonomy in conferring its nationality pursuant to its own legislation. ${ }^{16}$ This rule is reflected in Article 1 of the Hague Convention on Certain Questions Relating to the Conflict of Nationality Laws of 1930 (the 1930 Hague Convention), which reads: '[i]t is for each State to determine under its own law who are its nationals. ${ }^{17}$

15 Nottebohm (Liechtenstein v Guatemala), ICJ Reports (1955) 4, at 23 (hereinafter: Nottebohm).

16 ibid 20. See also M. Verwilghen, Conflits de Nationalité : Plurinationalité et Apatridie (1999) Martinus Nijhoff, at 4.

17 Art 1 of the 1930 Hague Convention. See also Art 3(1) of the 1997 European Convention on Nationality, which provides that: 'Each State shall determine under its own law who are its nationals.' See 
Yet, while states are free to legislate on matters concerning the attribution of nationality, it is for international law to determine the international effects of such attribution. ${ }^{18}$ Article 1 of the 1930 Hague Convention provides that the state's discretion to confer its nationality 'shall be recognised by other States in so far as it is consistent with international conventions, international custom, and the principles of law generally recognised with regard to nationality. ${ }^{19}$

In the Nationality Decrees case, the Permanent Court of International Justice (the PCIJ) acknowledged limits on the international recognition of nationality. The Court considered that the state's discretion to confer nationality is 'restricted by obligations which it may have undertaken towards other States'. ${ }^{20}$ In such a case, the Court continued, jurisdiction which, in principle, belongs solely to the State, is limited by rules of international law. ${ }^{21}$ In a similar vein, the ICJ acknowledged in Nottebohm that, by virtue of Article 1 of the 1930 Hague Convention, a nationality will only be recognized on the international plane if it is consistent with international criteria. $^{22}$

Thus, the international recognition of nationality, that is, by other states and international tribunals, is contingent upon international law requirements. ${ }^{23}$ The following paragraphs are confined to a brief examination of these requirements for the purposes of diplomatic protection and investment treaty arbitration.

\section{A. Nationality and the Customary International Law of Diplomatic Protection}

It is a fundamental principle of customary international law that a state is entitled to protect its nationals when harmed by wrongful acts committed by other states. ${ }^{24}$ Before the proliferation of investment treaties, the remedy most commonly used for the protection of aliens and their property was diplomatic protection. This remedy has been defined as the procedure employed by the State of nationality of the injured person to secure protection of that person and to obtain reparation for the internationally wrongful act inflicted'. ${ }^{25}$ It follows from this definition that the procedural right to exercise diplomatic protection belongs to the espousing state and not

also: Nationality Decrees issued in Tunis and Morocco (French Zone), PCIJ, Series B, No 4 (1923), 24 (hereinafter: Nationality Decrees case).

18 See generally AM Boll, Multiple Nationality and International law (2007) Martinus Nijhoff, 107; M Aghahosseini, Claims of Dual Nationals and the Development of Customary International Law (2007) Martinus Nijhoff, 76; OW Vonk, Dual Nationality in the European Union (2012) Martinus Nijhoff, 41-42 and P Weis, Nationality and Stateless in International Law (1979) Martinus Nijhoff, 59.

19 Art 1 of the 1930 Hague Convention.

20 Nationality Decrees (n 17) para 41.

21 ibid.

22 Nottebohm (n 15) 23.

23 JJ Caicedo-Demoulin and JF Merizalde-Urdaneta, 'El control de la Nacionalidad de los Inversionistas por los Árbitros Internacionales' (2009) 15 Revista Colombiana de Derecho Internacional 41, 47; Brigitte Stern, 'Les Problèmes de Nationalité des Personnes Physiques et de Nationalité et Contrôle des Personnes Morales devant le Tribunal des Différends Irano-Américains' (1984) 30 Annuaire Français de Droit International 425, 426; A Edwards and LV Wass, Nationality and Statelessness under International Law (2014) Cambridge University Press, 23-29.

24 Mavrommatis Palestine Concessions (Greece v UK), PCIJ, Series A, No 2 (1924), 12 (hereinafter: Mavrommatis).

25 CF Amerasinghe, Diplomatic Protection (2008) Oxford University Press, 25-26. 
the individual. ${ }^{26}$ In addition, and more significantly, the state's right to espouse a diplomatic protection claim is not an inherent one, but derives from the bond of nationality between the acting state and the injured individual. ${ }^{27}$

In principle therefore a state can only protect a person who holds its nationality. This requirement, generally known as the 'nationality of claims' rule, was incorporated in the Draft Articles on Diplomatic Protection, adopted by the International Law Commission in 2006 (the ILC Draft Articles). The ILC Draft Articles codify existing customary international law on nationality and the exhaustion of local remedies. ${ }^{28}$ In particular, Articles 3 and 4 confirm that 'the State entitled to exercise diplomatic protection is the State of nationality', ${ }^{29}$ that is, the state that confers its nationality in accordance with its own legislation. But does the possession of a nationality alone entitle a state to espouse a diplomatic protection claim on behalf of its national?

The fact that an individual holds the nationality of the claimant state does not mean that state is entitled to pursue a claim. An international tribunal may render unenforceable the right to diplomatic protection if the conferral or invocation of nationality fails to abide by customary law requirements. ${ }^{30}$ With regard specifically to our subject, one of these requirements can be found in Article 7 of the ILC Draft Articles, which reads as follows:

A State of nationality may not exercise diplomatic protection in respect of a person against a State of which that person is also a national unless the nationality of the former State is predominant, both at the date of injury and at the date of the official presentation of the claim. ${ }^{31}$

According to this provision, a dual national will be accorded diplomatic protection only if there was a stronger connection between that individual and the claimant state at the time of the injury and at the date when the claim was brought. This requirement, commonly referred to as the rule of dominant and effective nationality, has two main functions. First, it limits claims against the state of nationality with the aim of safeguarding the principle of sovereign equality. This principle prescribes that 'a person having dual nationality cannot make one of the countries to which he owes

26 This is because 'traditionally' individuals were considered objects of international law and as such they had no rights or obligations in the international plane. See generally J Crawford, The Creation of States in International Law (2006) Oxford University Press, 14-15; LFL Oppenheim, International Law: A Treatise (1905) Longmans, Green and Company, 16-17.

27 Panevezys-Saldutiskis Railway (Estonia v Lithuania), PCIJ, Series A/B, No 76 (1938), 16; Amerasinghe (n 25), 91 .

28 Arts 4-7 (rules for natural persons) and Art 14 (exhaustion of local remedies rule). See also A VermeerKünzli, 'As If: The Legal Fiction in Diplomatic Protection' (2007) 18(1) Eur J Int L 37, 40.

29 Arts 3 and 4 of the ILC Draft Articles. The only exception to the nationality of claims rule is that provided in art 8 , according to which a state may also protect refugees who are lawfully and habitually residing in its territory as well as stateless persons.

30 Art 4 of the ILC Draft Articles reads: 'For the purposes of the diplomatic protection of a natural person, a State of nationality means a State whose nationality that person has acquired, in accordance with the law of that State, by birth, descent, naturalization, succession of States, or in any other manner, not inconsistent with international law.' 
allegiance a defendant before an international tribunal'. ${ }^{32}$ Second, it seeks to avoid making international a claim that is purely domestic, which will occur if the dominant nationality is that of the defendant state. ${ }^{33}$

The ILC presented a non-exhaustive list of factors that may be taken into account in deciding dominant nationality. These factors include habitual residence, the amount of time spent in each country, family and economic ties in each country, and participation in social and public life, among others. ${ }^{34}$ The rule of dominant and effective nationality has been applied (or recognized) in a number of cases.

The Canevaro case, decided by the Permanent Court of Arbitration in 1912, is frequently cited in this connection. This is the first case in which an international tribunal has considered the issue of dual nationality in the context of diplomatic protection. The Court had to decide whether Italy was entitled to claim against Peru for damages suffered by Mr Canevaro, a dual Italian-Peruvian national. Peru objected to the claim on the basis that, in addition to being a Peruvian national, Mr Canevaro was more strongly and effectively connected to Peru than to the claimant state, Italy.

The Court agreed with Peru and found that Mr Canevaro repeatedly acted as a Peruvian national, even running for the Senate, and had been Peru's Consul General for the Netherlands. In line with the doctrine of dominant and effective nationality, the Court held that, although 'Canevaro's status as a national may be in Italy, the Government of Peru has a right to consider him a Peruvian citizen and to deny his status as an Italian claimant'. ${ }^{35}$ Thus, the Court declined jurisdiction over $\mathrm{Mr}$ Canevaro's claim.

The Nottebohm case is also cited (or confused) as dealing with issues of dual nationality. This is perhaps because $\mathrm{Mr}$ Nottebohm was never a dual national. $\mathrm{He}$ only had the nationality of the principality of Liechtenstein when the state brought a diplomatic protection claim on his behalf. Rather, the relevant question for the Court was whether Guatemala was entitled not to recognize Mr Nottebohm's Liechtenstein nationality, and thus to prevent Liechtenstein from exercising diplomatic protection. In determining this issue, the Court applied a test of 'genuine or effective' nationality and found that, given the lack of a genuine link between

32 ZR Rode, 'Notes and Comments: Dual Nationals and the Doctrine of Dominant Nationality' (1959) 53 Am J Int L 139, 141. The principle of sovereign equality of states is reflected in art 4 of the 1930 Hague Convention: 'A State may not afford diplomatic protection to one of its nationals against a State whose nationality such person also possesses.' This rule is absolute and applied irrespective of issues of dominance and effectiveness. It was however considered to be too restrictive and inconsistent with contemporary international law. Therefore, with the aim to accord greater protection to individuals, the principle of equality was tempered by the doctrine of dominant and effective nationality only in cases where the dominant nationality was that of the claimant state. See generally WL Griffin, 'International Claims of Nationals of Both the Claimant and Respondent States - The Case History of a Myth' (1967) 1(3) Intl Lawyer 400, 423. For a comprehensive discussion on this issue see the Commentaries to the ILC Draft Articles, text adopted by the ILC at its fifty-eighth session and submitted to the General Assembly as a part of the Commission's report covering the work of that session A/61/10 (2006), 43-47 (hereinafter: the ILC Commentaries).

33 Case concerning the loss of property in Ethiopia owned by non-residents (Eritrea $v$ Ethiopia), Eritrea-Ethiopia Claims Commission, Partial Award, 19 December 2009, para 11.

34 The ILC Commentaries (n 32) 46. The ILC emphasized that these elements are by no means determinative and that tribunals and courts enjoy full discretion to ascertain the relevance of each factor. 
Liechtenstein and Mr Nottebohm, Guatemala was not obliged to recognize his nationality.

The ICJ therefore preferred to extend the principle of dominant and effective nationality to the recognition or opposability of only one nationality. Nonetheless, the Nottebohm case is relevant for our purposes since the ICJ acknowledged that the dominant and effective nationality test also applies to resolve the problem of dual nationality:

International arbitrators have decided in the same way numerous cases of dual nationality, where the question arose with regard to the exercise of protection. They have given their preference to the real and effective nationality, that which accorded with the facts, that based on stronger factual ties between the person concerned and one of the States whose nationality is involved. ${ }^{36}$

Another leading case on dual nationality is the Mergé case, brought before the USItaly Conciliation Commission. It involved a claim submitted by the United States for compensation for the loss of personal property located in Italy and owned by Mrs Mergé. Italy objected to the claim arguing that Mrs Mergé, a dual national of the United States and Italy, should be prevented from claiming against Italy on the basis of the aforementioned principle of sovereign equality.

The Commission considered that the United States was entitled to exercise protection only if the dominant and effective nationality of Mrs Mergé was that of the United States, the claimant state. The Commission famously stated that:

The principle, based on the sovereign equality of States, which excludes diplomatic protection in the case of dual nationality, must yield before the principle of predominant nationality whenever such nationality is that of the claiming State. But it must not yield when such predominance is not proved, because the first of these two principles is generally recognized and may constitute a criterion of practical application for the elimination of any possible uncertainty. ${ }^{37}$

After determining that Mrs Mergé had a stronger connection with Italy (her habitual residence was in Italy, she was married to an Italian national, she usually travelled with an Italian passport, etc.), the Commission held that she could not be considered as having dominant US nationality. The Commission applied the rule of dominant and effective nationality in over 50 subsequent cases. ${ }^{38}$

Relying on these decisions, the Iran/US Claims Tribunal has applied the principle of dominant and effective nationality in a number of cases involving claims by dual US-Iranian nationals. ${ }^{39}$ The Esphahanian case, which later became Case $A / 18$, is

37 Mergé case (United States v Italy), US-Italy Conciliation Commission, 14 Recueil des Sentences Arbitrales (1955), 247-48. 
often cited as the leading case in this context. ${ }^{40}$ The claimant instituted arbitration proceedings against Iran under the Algiers Accords. ${ }^{41}$ It is notable that, as with the BIT applicable in Serafin, the Algiers Accords do not regulate the question of dual nationality. The only nationality requirement is that provided in Article VII(1)(a): '[a] "national" of Iran or of the United States, as the case may be, means . . a natural person who is a citizen of Iran or the United States. ${ }^{, 42}$

Iran objected to the jurisdiction of the Tribunal arguing that, in line with the customary law of diplomatic protection, Article $\mathrm{VII}(\mathrm{I})(\mathrm{a})$ should be read as extending protection to nationals of Iran or the United States but not of both. ${ }^{43} \mathrm{Mr}$ Esphahanian responded that the language of that provision is clear and unambiguous and that it applies to all nationals of the United States and of Iran, including dual nationals, without restriction'. ${ }^{44}$

The Tribunal rejected Mr Esphahanian's argument emphatically, holding that:

[C]laimant's interpretation leads to an absurd result in that it would permit dual nationals to make claims before the Tribunal against either Government, or both. If dual nationals can claim on the simplistic ground that there is no provision prohibiting them from doing so, then there is no basis for refusing them the right to claim under either of their nationalities. ${ }^{45}$

In the Tribunal's view, when a treaty is silent on a particular issue, such as dual nationality, it is necessary to resort to the interpretative principles of the Vienna Convention of the Law of Treaties (the VCLT) in order to fill the gap left in the treaty. ${ }^{46}$ The Tribunal referred, in particular, to Article 31(3)(c) of the VCLT, which requires the application of 'any relevant rules of international law applicable in the relations between the parties'. In this respect, the Tribunal held that the applicable rule of international law to resolve the question of the standing of dual nationals was that of dominant and effective nationality. ${ }^{47}$ This rule, the tribunal continued, should be understood as consistent with the nationality definition provided in Article $\mathrm{VII}(1)(\mathrm{a})$ of the Algiers Accords 'unless an exception is clearly stated'. ${ }^{48}$ However, given that the Algiers Accords do not expressly exclude the application of the rule and are silent on the issue of dual nationality, the tribunal did not find such an exception in the instant case.

Accordingly, the Tribunal concluded that it could only hear the claimant's claims provided that his dominant nationality was that of the United States, the home state.

40 Esphahanian v Bank Tejarat, 2 Iran-U.S.C.T.R. (1983) (hereinafter: Esphahanian). See also Case No A/18, 5 Iran-U.S.C.T.R. (1984) (hereinafter: Case A/18).

41 The Algiers Accords were created to resolve the hostage crisis between Iran and the United States. Pursuant to these agreements, the Iran-US Claims Tribunal was established in 1981 to adjudicate claims by nationals of each country following the Iranian revolution.

42 See art VII(1)(a) of the Algiers Accords.

43 Esphahanian (n 40) 160-61.

44 ibid.

45 ibid.

46 ibid.

47 ibid.

48 Case $A / 18$ (n 40) 25. 
After having found that the claimant had more substantive ties with the United States, the Tribunal upheld jurisdiction and proceeded to the merits of the dispute. In other cases, however, the Tribunal applied the rule and declined jurisdiction when the dominant nationality was that of the respondent state. ${ }^{49}$

To sum up, pursuant to the customary law of diplomatic protection, holding the nationality of the claimant state does not by itself suffice to obtain protection on the international plane. In cases of dual nationality, the right to bring a claim shall be exercisable only by the state of the dominant nationality. This position has also been adopted in proceedings initiated outside the interstate system of diplomatic protection. Indeed, despite the fact that the Algiers Accords grant direct right of action to injured individuals, ${ }^{50}$ the Iran/US Tribunal ascertained its jurisdiction under that treaty by reference to the customary rule of dominant and effective nationality. It could therefore be said that the Tribunal did not consider the Algiers Accords to be self-contained, but rather to be an international treaty that integrates other sources of international law.

\section{B. Nationality and International Investment Law}

As described above, under traditional international law, private claims of individuals were commonly settled through the remedial institution of diplomatic protection. Under this mechanism, only the state of nationality holds the procedural right to bring claims on behalf of its nationals. Moreover, before that state espouses the claim of its national, the affected person must exhaust local remedies available in the host state. $^{51}$ This system was considered as an inefficient and highly unpredictable means for obtaining redress for violations of international law. As such, in an effort to protect and promote foreign investment, states decided to insulate the settlement of international disputes from the realm of politics and diplomacy. In doing so, they began to conclude investment treaties providing for the direct settlement of disputes between investors and host states. Commonly, these provisions allow investors to refer their disputes to arbitral institutions or to ad hoc tribunals without having to exhaust local remedies in the host state. The majority of international treaty arbitrations are conducted under the auspices of the ICSID Convention or, as in Serafin, the UNCITRAL Arbitration Rules. ${ }^{52}$

49 See, eg, Michelle Danielpour v Iran, Case No 424-168-3, 16 June 1989; August Frederick Benedix, et al v Iran, Case No 412-256-2, 22 February 1989; Anita Perry-Rohani, et al v Iran, Case No 427-831-3, 30 June 1989; Benny Diba v Iran, Case No 444-940-2, 31 October 1989; Raymond Abboud, as legal representative of Christine Arianne Abboud v Iran, Case No 477-383-2, 16 May 1990; Reza Nemazee, et al v Iran, Case No 487-4-3, 10 July 1990.

50 The Algiers Accords were established to resolve disputes between private claimants and the states party, thereby departing from the system of diplomatic protection. In the words of the Tribunal: 'the agreement of the two Governments to create this Tribunal was not a typical exercise of diplomatic protection of nationals in which a State, seeking some form of international redress for its nationals, creates a tribunal to which it, rather than its nationals, is a party'; See Esphahanian (n 40) 165.

51 Art 14(1) of the ILC Draft Articles states that: 'A State may not present an international claim in respect of an injury to a national or other person referred to in draft article 8 before the injured person has, subject to draft article 15 , exhausted all local remedies.'

52 United Nations Conference on Trade Law and Development (UNCTAD), Investor-State Dispute Settlement: Review of Developments in 2016 , http://investmentpolicyhub.unctad.org/Upload/Documents/ diaepcb2017d1_en.pdf accessed 30 May 2017. 
Despite offering two procedurally distinct mechanisms for the resolution of international disputes, diplomatic protection and investment treaty arbitration have retained nationality as a fundamental requirement. Indeed, as with diplomatic protection, the operation of investment treaties is dependent upon the link of nationality between the individual and the home state. Investment treaties generally contain a definition of the term 'investor' requiring that, to qualify for treaty protection, any natural person must be a national of the home state. Article 1 of the US-Argentina BIT provides a typical formulation: 'investor' means a 'a natural person who is a national of a Party under its applicable law. 53

It is interesting to note that the definition of the term 'investor' in investment treaties is virtually identical to the rule of diplomatic protection concerning the nationality of claims, as codified in the ILC Draft Articles. By way of reminder, the nationality of claims rule also provides that the individual must have the nationality of the claimant state in accordance with its own legislation. Thus, far from displacing customary law, states have also decided to limit the protection afforded in investment treaties to nationals of the home state.

However, the language of investment treaties is broadly drafted and does not normally go beyond the nationality of claims rule. This means that most investment treaties fail to address the question of dual nationality. ${ }^{54}$

\section{(i) Dual nationality and the ICSID Convention}

One of the very few treaties that does regulate the issue of dual nationality is the ICSID Convention, Article 25(2)(a) of which provides that:

National of another Contracting State' means:

(a) any natural person who had the nationality of a Contracting State other than the State party to the dispute on the date on which the parties consented to submit such dispute to conciliation or arbitration as well as on the date on which the request was registered ... but does not include any person who on either date also had the nationality of the Contracting State party to the dispute. $^{55}$

Thus, Article 25(2)(a) creates both 'positive' and 'negative' nationality requirements: the investor must have the nationality of the home state but cannot also have the nationality of the host state. ${ }^{56}$ This means that physical persons holding the nationality of both states party to an investment treaty are excluded from ICSID jurisdiction. The exclusion is absolute: it applies irrespective of arguments as to which nationality is more effective. ${ }^{57}$ 
In Champion Trading $v$ Egypt, the claimants were found to be dual nationals of the United States and Egypt at the relevant times. ${ }^{58}$ Egypt challenged jurisdiction on the basis that the claimants had failed to satisfy the 'negative' requirement of Article 25(2)(a) of the ICSID Convention. The claimants responded that the customary rule of dominant and effective nationality applied to dual nationals, even if they were expressly excluded from the Convention's scope of protection. In this respect, the claimants contended that, since they had more substantive ties with the United States (the home state) than with Egypt, the Egyptian nationality could be disregarded when considering the application of Article 25(2)(a).

The tribunal rejected the claimants' argument, holding that the ICSID Convention left no room for the application of the dominant and effective nationality test, precisely in light of the 'clear and specific rule' in Article 25(2)(a). ${ }^{59}$ To substantiate its finding, the tribunal relied on the decision of the Iran/US Claims Tribunal in Case A/18. As noted earlier, in that case, the Iran/US Claims Tribunal observed that 'unless an exception is clearly stated ${ }^{60}$ in the Algiers Accords, the rule of dominant and effective nationality should apply to claims by dual nationals. The tribunal in Champion Trading considered that the 'exception' referred to in Case $A / 18$ was reflected in Article 25(2)(a) and thus discarded the application of the rule. ${ }^{61}$ Put differently, given that the ICSID Convention provides an explicit and absolute exclusion of dual nationals, there was no need for the tribunal to determine the dominant nationality of the claimants.

It can be argued that, by relying on the Iran/US Claims Tribunal jurisprudence, the Champion Trading tribunal implicitly agreed that when a treaty does not expressly exclude dual nationals, or simply fails to regulate this issue, the rule of dominant and effective nationality may apply as a lacuna filing instrument.

As explained further below, the tribunal in Serafin did not uphold this view, nor the one adopted by the Iran/US Claims Tribunal, preferring instead to interpret the silence in the Spain-Venezuela BIT on dual nationality as an agreement by the contracting parties to be sued by their own nationals.

\section{(ii) Dual nationality outside the ICSID Regime}

Insofar as published decisions are concerned, Serafin is the first investment treaty case in which a dual national brought a treaty claim outside the ICSID Regime. As described in the introduction, the claimants, two Spanish-Venezuelan nationals, initiated UNCITRAL arbitration proceedings against Venezuela under the SpainVenezuela BIT. Neither the BIT nor the UNCITRAL Arbitral Rules contain a provision regulating the issue of dual nationality. Article 1 of the BIT defines 'investor' simply as 'personas físicas que tengan la nacionalidad de una de las Partes Contratantes con arreglo a su legislación'. ${ }^{62}$

Champion Trading Company, Ameritrade International, Inc, James T Wahba, John B Wahba, and Timothy T Wahba v Arab Republic of Egypt, ICSID Case No ARB/02/9, Decision on Jurisdiction, 21 October 2003 (hereinafter: Champion Trading).

59 ibid 16.

60 ibid. See also Case $A / 18$ (n 40) 25.

61 ibid 16.

62 Art 1 of the Spain-Venezuela BIT. “investors” mean a) physical persons who are nationals of one of the Contracting States in accordance with its legislation.’ 
Venezuela objected to the jurisdiction of the tribunal, arguing that natural persons who have the nationality of both contracting states are excluded from the scope of application of the treaty, especially if they are more closely linked to the respondent state. In line with the position adopted by the Iran/US Claims Tribunal, Venezuela contented that the right approach in the instant case was to fill the gap left in the treaty through the application of the customary rule of dominant and effective nationality, as required by Article 31(3)(c) of the VCLT.

Thus, according to Venezuela, the tribunal's jurisdiction ratione personae should be extended to the claimants only if their dominant nationality was that of the home state, Spain. On the facts, however, it was clear that the dominant nationality of the claimants was Venezuelan, given the long-standing relationship that they had developed with that country for several years. In fact, the only substantive link that they had with Spain was a passport confirming their status as nationals of that country.

The tribunal declined to follow Venezuela's arguments that the question of the standing of dual nationals under the BIT should be governed by the customary rules of diplomatic protection. ${ }^{63}$ In making this finding, the tribunal examined the legal nature of diplomatic protection and investment treaties. It observed that the rules relating to diplomatic protection-such as the dominant and effective nationality test-were developed at a time when states were the only bearers of rights and obligations under international law. However, the tribunal continued, investment treaties have departed from the traditional system of diplomatic protection by enabling investors to vindicate their own rights before international tribunals. ${ }^{64}$ According to the tribunal, the direct access of investors to international arbitration to enforce their treaty rights means that investment treaties have derogated from the customary law of diplomatic protection: ${ }^{65}$

[L] a existencia de un mecanismo de solución directa de diferencias entre inversores y el Estado receptor de la inversión retira la protección diplomática del contexto de los tratados de inversión por ser inconsistente con las reglas de los TBIs. ${ }^{66}$

For the tribunal, this approach was confirmed by Article 17 of the ILC Draft Articles, which states that: '[t] he present draft articles do not apply to the extent that they are inconsistent with special rules of international law, such as treaty provisions for the protection of investments.' Therefore, in the tribunal's view, the customary rule of dominant and effective nationality, codified in the ILC Draft Articles, was not consistent with the BIT's nationality requirement-even if the latter failed to regulate the question of dual nationality. ${ }^{67}$ The tribunal took this view despite the fact that, by virtue of the agreement reflected in the dispute resolution clause of the BIT, it was

ibid.

66 ibid para 173. 'The mechanism for the direct resolution of disputes between investors and the host State abandons diplomatic protection in the context of investment treaties for being inconsistent with the rules found in BITs.' 
obliged to apply 'rules and principles of international law' in addition to the terms of the treaty. ${ }^{68}$

In short, the tribunal asserted that the BIT's nationality requirement-which merely provides that an investor must be a national of the home state-was the sole criterion to be applied to determine the claimants' standing under the treaty. As nationals of Spain, the claimants qualified as protected investors and, therefore, had standing under the BIT.

The Serafin tribunal is not alone in finding that investment treaties create a legal framework (or lex specialis) that displaces the customary rule of dominant and effective nationality. In a previous case, Pey Casado $v$ Chile, the tribunal was of the view that, insofar as the applicable investment treaty does not explicitly exclude dual nationals, an investor could rely on that treaty to sue his or her state of nationality.

Pey Casado related to claims under the Spain-Chile BIT brought by Mr Pey Casado, a national of Spain. ${ }^{69}$ It is notable that Mr Pey Casado instituted arbitration proceedings pursuant to the ICSID Convention and not the UNCITRAL Arbitration Rules, as the investors did in Serafin. The main jurisdictional question was whether Mr Pey Casado was, at the relevant times, also a Chilean national and therefore failed to comply with the 'negative' requirement in Article 25(2)(a) of the ICSID Convention. In response to an objection by Chile, the tribunal found that $\mathrm{Mr}$ Pey Casado had renounced his Chilean nationality before submitting his request for arbitration. $^{70} \mathrm{He}$ was not therefore a dual national for the purposes of Article $25(2)(a)$, that is to say, he did not sue his state of nationality.

However, the tribunal did not stop there. Despite holding that Mr Pey Casado did not have the nationality of the host state at the relevant dates, and consequently had jurisdiction under the ICSID Convention, the tribunal went on to examine whether the Spain-Chile BIT extended protection to dual nationals. The tribunal asserted that, in ascertaining jurisdiction under the Spain-Chile BIT, it should confer primacy to the lex specialis language of treaty. ${ }^{71}$ It then noted that, contrary to Article 25(2)(a) of the ICSID Convention, the Spain-Chile BIT did not expressly exclude dual nationals from its scope of application. ${ }^{72}$ Indeed, as most investment treaties, the Spain-Chile BIT only requires that the investor be a national of the home state. ${ }^{73}$ The tribunal viewed this requirement as one that shuts the door on the customary rule of dominant and effective nationality:

[E]l tratamiento bajo el APPI de los dobles nacionales es diferente del previsto en el Convenio CIADI en cuanto a su ámbito de aplicación y a su contenido. Para

See Art XI (4) of the Spain-Venezuela BIT, which provides that: 'The arbitral dispute must be resolved through the application of a) the terms of the present agreement and any other agreements concluded between the States party: b) the rules and principles of international law; and c) the national law of the host State, including its conflict of law rules.'

69 Victor Pey Casado and President Allende Foundation v Republic of Chile, ICSID Case No ARB/98/2, Award, 8 May 2008 (hereinafter: Pey Casado).

70 ibid para 317.

71 ibid paras $412-13$.

72 ibid para 415.

73 ibid para 413. See art 1 of the Spain-Chile BIT, which defines protected investors as 'natural persons or nationals in accordance with the legislation of the corresponding State'. 
cumplir la condición de la nacionalidad de acuerdo al APPI, basta con que la parte demandante demuestre que tiene la nacionalidad del otro Estado contratante. A diferencia de lo que sostiene la Demandada, el hecho de que la Demandante posea doble nacionalidad, que comprende la nacionalidad de la Demandada, no la excluye del ámbito de aplicación del APPI. En opinión del Tribunal de arbitraje, en este contexto no existe la condición de nacionalidad "efectiva y dominante" de los dobles nacionales. Un doble nacional no queda excluido del campo de aplicación del APPI aunque su nacionalidad "efectiva y dominante" sea la del Estado en el que se realiza la inversión. ${ }^{74}$

As the quote shows, the tribunal concluded that, pursuant to the plain terms of the BIT, the fact that the investor holds the nationality of the home state is sufficient for him or her to claim under the treaty, even if he or she simultaneously holds the nationality of the host state.

It is important to note, however, that the tribunal made these comments obiter dicta. The relevant issue in that case was not the standing of dual nationals under the Spain-Chile BIT, but rather the tribunal's finding that Mr Pey Casado had renounced his Chilean nationality before consenting to ICSID arbitration. ${ }^{75}$ In other words, the tribunal in that case was not factually called upon to determine whether the SpainChile BIT entitled a dual national to claim against his or her state of nationality. This is simply because, contrary to the status of the investors in Serafin, Mr Pey Casado only held the nationality of the home state at the time he initiated arbitration proceedings. Despite this, the Serafin tribunal relied on the obiter dicta in Pey Casado when ascertaining its jurisdiction under the Spain-Venezuela BIT. ${ }^{76}$

\section{Concluding observations}

As the first publicly known decision on the standing of dual nationals outside the ICSID regime, the Serafin award is certainly having an impact on investment treaty practice. This decision has, on the one hand, already influenced tribunals that are currently hearing claims by investors against their state of nationality. For instance, in Uzan $v$ Turkey, a tribunal constituted pursuant to the arbitration rules of the Stockholm Chamber of Commerce (SCC) recently held that Mr Uzan, a Turkish national residing in France, was entitled to sue Turkey under the ECT. Both the SCC Arbitration Rules and the ECT are silent on the issue of dual nationality. The arbitrators, citing the tribunal in Serafin, considered that the ECT is lex specialis and as such that it should apply in isolation from the customary rule of dominant and

74 Pey Casado (n 69) para 415. 'Under the BIT dual nationals are treated differently than under the ICSID Convention with regard to applicability and content. To meet the criteria for nationality for the purposes of the BIT, it suffices that the claimant demonstrates that he has the nationality of the home state. Contrary to what the Respondent contends, the fact that the claimant possesses dual nationality, including the nationality of the Respondent state, does not exclude him from the scope of the BIT. In the Tribunal's view, the rule of "effective and dominant" nationality is irrelevant in the present case. A dual national is not excluded from the scope of the BIT even if his "effective and dominant" nationality is that of the State where he made the investment.'

75 JE Anzola, 'Dual Nationality in Investment Arbitration: The Case of Venezuela' (2016) Transn Dis Manage, 29.

76 Serafín (n 5) para 204. 
effective nationality. They further conceded with the view that, in accordance with Article 17 of the ILC Draft Articles on Diplomatic protection, the language of the ECT was inconsistent with that rule. ${ }^{77}$

On the other hand, the Serafin award has, unsurprisingly, increased the potential for claims by dual nationals. ${ }^{78}$ An example includes an ongoing UNCITRAL arbitration initiated on 21 September 2015 by Russian oligarch Sergei Pugachev. ${ }^{79} \mathrm{Mr}$ Pugachev, who is also a French national, brought a claim against Russia under the France-Russia BIT. In his request for arbitration, he asserted that since ' $[\mathrm{n}]$ either the France-Russia BIT nor the UNCITRAL Rules preclude dual nationals from bringing claims against either of the State contracting parties', he is entitled to claim against Russia. ${ }^{80}$

Interestingly, one year after Mr Pugachev filed the claim, the Russian Government enacted a new regulation on the conclusion of investment treaties, as part of the state's plan to change its policy on negotiating investment treaties. ${ }^{81}$ In this regulation, Russia has made clear that future treaties should not be applicable to investors who, as Mr Pugachev, are also nationals the host state, thereby seemingly foreclosing the potential for UNCITRAL claims being brought by investors against their state of nationality.

One would expect more states to adopt Russia's policy as treaty claims by dual nationals continue to arise, and it remains to be seen whether more tribunals will follow the approach taken in Serafín. The question remains whether a host state must submit to the jurisdiction of an arbitral tribunal in a dispute involving its own national. Formulated differently, should the formal nationality requirements provided by most investment treaties be understood to encompass the diplomatic protection rules of nationality? The answer to this question will depend on the relationship between the law of diplomatic protection and international investment law. When examining this relationship, most tribunals and scholars have found that the rules derived from the interstate system of diplomatic protection cannot be imported into a field where individuals are entitled to directly enforce treaty obligations. ${ }^{82}$

77 Uzan $v$ Turkey (n 14) paras 141-44.

78 See $\mathrm{n} 13$ above for a list of cases where dual nationals have initiated arbitration proceedings against their state of nationality.

79 Sergei Viktorovich Pugachev $v$ the Russian Federation, UNCITRAL, Notice of Arbitration, 21 September 2015.

80 ibid para 115 .

81 IA Reporter, Investment Arbitration Reporter, 'Russia sets out new guidelines for contents of future investment treaties', <http://www.iareporter.com/articles/russia-sets-out-new-guidelines-for-negotiationof-future-investment-treaties/> accessed 30 May 2017. The new regulation in Russian is available at $<$ http://pravo.gov.ru/proxy/ips/?docbody=\&prevDoc $=102071479 \&$ backlink $=1 \& \&$ nd $=102412$ 234> accessed 30 May 2017.

82 See, eg, RA Luzzi and B Love, 'Individual Nationality in Investment Arbitration: the Tension Between Customary International Law and Lex Specialis' in AK Bjorklund and others (eds), Investment Treaty Law: Current Issues III: Remedies in International Investment Law \& Emerging Jurisprudence in International Investment Law (London British Institute of International and Comparative Law 2009), 185; P Bernardini, 'Continuous nationality Rule in Investment-State Arbitration' in M Kinnear and others (eds), Building International Investment Law: The First 50 Years of ICSID (Kluwer Law International 2015), 164 65; B Juratowitch, 'The Relationship between Diplomatic Protection and Investment Treaties' (2008) 23(1) ICSID Rev, 11-14; Ioan Micula, Viorel Micula, S.C. European Food S.A, S.C. Starmill S.R.L. and S.C. 
According to this majority view, the direct settlement of disputes between investors and host states constitutes a total departure from the law of diplomatic protection and its rules of nationality, as if the investment treaty regime was self-contained. This contribution takes a different approach.

The main characteristic of a self-contained regime is indeed to completely displace the general international law of state responsibility, which includes the customary rules of diplomatic protection. ${ }^{83}$ However, even if state parties have granted investors special protection and direct access to arbitration in investment treaties, the author contends that the rules set out in these instruments do not automatically displace or are otherwise inconsistent with those of diplomatic protection. A closer look at the nature of diplomatic protection and investment treaty arbitration compels a different conclusion.

Despite arguments to the contrary, diplomatic protection and investment treaty arbitration share certain elements that integrate the rules established under each system. One of these elements has already been identified: the right to diplomatic protection and the operation of investment treaties are both dependent upon the link of nationality between the individual and the home state. This means that investors and individuals seeking diplomatic protection are not recognized as international persons independently of their home states. ${ }^{84}$

As shown in the next section, a further more fundamental element of integration of diplomatic protection and investment treaty arbitration relates to the question of who, the investor or the state, holds the substantive rights granted under both systems. It will be argued in this context that the underlying rights conferred in diplomatic protection and investment treaty arbitration are of a 'dual' nature, i.e., they belong to both the state and its national. This is demonstrated, inter alia, by the fact that diplomatic protection and investment treaties alike enable states to espouse claims on behalf of their nationals.

In the author's view, these elements show that states did not intend investment treaties to be exhaustive and complete. Therefore, as a part of customary international law, the diplomatic protection rules of nationality, including the dominant and effective nationality test, should apply to the extent that the applicable investment treaty contains no explicit derogation. This becomes especially clear when the treaty is silent on a particular issue, such as dual nationality. Thus, the customary rule of the dominant and effective nationality would not be inconsistent with the treaty nationality requirements, unless the rule is expressly excluded from the scope of application of the treaty.

Multipack S.R.L. v Romania, ICSID Case No ARB/05/20, Award on Jurisdiction, 24 September 2008, para 101; Pey Casado (n 69) para 415; Serafín (n 5) para 173.

83 B Simma and D Pulkowski, 'Leges Speciales and Self-Contained Regimes' in J Crawford and others (eds), The Law of International Responsibility, Oxford Commentaries on International Law (Oxford University Press 2010), 142.

84 This differs from the ambit of human rights law in which the individual's ability to bring international claims does not depend on the state to which he or she is linked by nationality. Indeed, protection in the field of human rights will be afforded even if the individual is a stateless person and his or her state of nationality is not a party to the relevant human rights treaty. It is sufficient that the state against which the individual intends to bring a claim has ratified that treaty. See AA Cançado Trindade, The Access of Individuals to International Justice (2011) Oxford University Press, 28 and footnote 38. 


\section{THE DUAL NATURE OF THE RIGHTS ASSERTED IN INTERNATIONAL CLAIMS}

The relationship between the law diplomatic protection and international investment law has often been examined by reference to the nature of the rights conferred in investment treaties. In this regard, Douglas has famously argued that:

$[\mathrm{T}]$ he contracting states to investment treaties have legislated for a new legal regime or sub-system to define the legal consequences that follow a violation of the minimum standards of treatment towards a qualified investment. In relation to the investor/state sphere, a breach of a treaty standard by the host state certainly creates new obligations upon that state. But these new obligations do not correspond to new rights of the national state of the investor because the injury is caused exclusively to the investor. This is so because the contracting states have opted out of the inter-state secondary rules of state responsibility in relation to a limited group of wrongs causing damage to a particular sphere of private interests. The national state of the investor thus has no immediate secondary rights within the investment treaty regime to challenge the commission of this breach of treaty; instead the new rights arising upon the breach of treaty vest directly in the investor. ${ }^{85}$

This approach assumes that, whereas the rights asserted in diplomatic protection are owed on an interstate basis only, in investment treaty arbitration the investor is vindicating its own rights through the invocation of the dispute resolution mechanism available in the applicable investment treaty. In other words, since investment treaties confer no rights upon states, the rules of diplomatic protection should not be imported into the investment treaty regime. Further commentators and tribunals have adhered to Douglas' position, implicitly conceding that investment treaties are self-contained instruments designed to exclude completely the general regime of state responsibility. ${ }^{86}$

This contribution takes a different view and argues that the rights invoked in both diplomatic protection and investment treaty claims are jointly held by the individual and the home state. This common element between the two systems suggests that international investment law integrates the nationality rules of diplomatic protection.

\section{A. The Nature of the Rights Asserted in Diplomatic Protection}

As we have seen, only the state of nationality has the 'procedural' right to exercise diplomatic protection on behalf of its national, but it is unclear whether in doing so that state is vindicating its own substantive rights, that of its national, or both.

The classic rule on the matter was originally established in Mavrommatis, where the PCIJ held that:

$[\mathrm{B}] \mathrm{y}$ taking up the case of one of its subjects and by resorting to diplomatic action or international judicial proceedings on his behalf, a State is in reality 
asserting its own right, the right to ensure, in the person of its subjects, respect for the rules of international law. ${ }^{87}$

According to this approach, the rights derived from the general international law of diplomatic protection arise exclusively between states. The claiming state is thus considered to have the procedural right to enforce its own substantive rights only. ${ }^{88}$ Clearly, a state exercising diplomatic protection on behalf of its national has a right in the claim. This right derives from the injury caused to its national as a result of the wrongful act committed by another state. As Professor Amerasinghe has stated: 'the rule that the injured alien must have the nationality of the claimant State ... flows from account being taken of the national State's interest. ${ }^{89}$

Yet, it makes little sense to assert that, in bringing a claim through diplomatic espousal, the claimant state is enforcing its own substantive rights only. In reality, that state is acting as an advocate for its national, whose rights have also been violated. The real dispute that stands at the basis of diplomatic protection is between the respondent state and the individual who ultimately suffers from a violation of international law. ${ }^{90}$ In his First Report on State Responsibility, Special Rapporteur of the ILC Francisco García-Amador explained that 'the injured interest or right in the cases of responsibility to which the rule [of diplomatic protection] applies is primarily that of the private individual and not that of the State.' 91

One can therefore argue that two rights are involved in the exercise of diplomatic protection: (i) the right of the individual who has been harmed and (ii) the right of the state that acts on his or her behalf. ${ }^{92}$ Therefore, a diplomatic protection claim may be considered as being of a 'dual' nature: it results from an injury caused to both the state and its national. In the words of the ILC: '[a] State does not "in reality" - to quote Mavrommatis - assert its own right only. "In reality" it also asserts the right of its injured national. ${ }^{93}$ This dualistic nature of the claim was confirmed by the ICJ in a number of cases. ${ }^{94}$

87 Mavrommatis (n 24) 12.

88 E de Vattel, Le Droit des Gens ou Principes de la Loi Naturelle (1758), i, bk II, para 71; the ILC Commentaries (n 32) 24-25.

89 Amerasinghe (n 25) 66. See also FV García Amador, 'State Responsibility: Some New Problems' (1959) 94 Recueil des Cours de l'Académie de Droit International de La Haye, 414-15; Interhandel case (Switzerland v United States) (Preliminary Objections) [1959] ICJ Reports 6, 25.

90 Vermeer (n 28) 40.

91 FV Garcia-Amador, 'Report on International Responsibility', ILC, ACN.4/96 (1956), 196.

92 Vermeer (n 28) 66-67, relying on Santulli, 'Entre Protection Diplomatique et Action Directe: La Représentation', in le Sujet en Droit International : colloque du Mans/Société française pour le Droit International (2005), 85-98.

93 The ILC Commentaries (n 32) 25. See also A Pellet, 'The Second Death of Euripide Mavrommatis? Notes on the International Law Commission's Draft Articles on Diplomatic Protection' (2008) 7(1) L Pract Int Courts Tribunals, para 30; Vermeer (n 28) 57; L Dubois, 'La Distinction entre le droit de l'Etat réclamant et le Droit du Ressortissant dans la Protection Diplomatique' (1978) 67 Revue Critique de Droit International Privé, 621; FO Vicuna, 'The Changing Law of Nationality of Claims', Report for the International Law Association Committee on Diplomatic Protection of Persons and Property, 69th Conference (2000), 633-34.

94 See, eg, Case Concerning Elettronica Sicula SpA (United States v Italy), ICJ Reports (1989) 15, paras 48-49 (hereinafter: ELSI); LaGrand (Germany v United States), ICJ Reports (2001) 466, para 77 (hereinafter: 
For instance, in ELSI, the United States brought a diplomatic protection claim on behalf of two US companies under the US-Italy Friendship, Commerce and Navigation (FCN) Treaty. The Court held that the claim represented the rights of both the United States and the companies in whose favour that state was acting. In this regard, the Court held that it was unable 'to find a dispute over alleged violation of the FCN Treaty resulting in direct injury to the United States, that is both distinct from, and independent of, the dispute over the alleged violation in respect of [the US companies]' 95

Similarly, the ICJ affirmed in LaGrand and Avena that a diplomatic protection claim brought for a violation of an international norm may affect both the rights of the home state and the rights of its national. In LaGrand, the United States argued that the rights of consular notification and access under the Vienna Convention on Consular Relations (VCCR) were rights of states only. In rejecting this argument, the ICJ clarified that the VCCR also created individual rights. ${ }^{96}$ In Avena, the ICJ further noted that the rights conferred by the VCCR rights were 'interdependent', meaning that the rights of the espousing state are inextricably linked to the rights of the person on whose behalf it is acting. ${ }^{97}$ For the Court, the injury caused to the state of nationality should be considered as inseparable from the injury suffered by the protected person. This contribution contends that the same is true in the context of investment treaties.

\section{B. The Nature of the Rights Granted in Investment Treaties}

As described above, one of the most salient features of investment treaties is that they grant investors the 'procedural' right to commence arbitration proceedings against host states. The question is then whether the substantive investment protection obligations are owed to the investor, its home state or both.

It is surprising that, to date, the nature of the rights conferred by investment treaties has not been sufficiently defined. This is all the more astounding since the nature of investors' rights is not only of theoretical interest, it becomes relevant when determining the position of the customary diplomatic protection rules of nationality amidst the investment treaty regime. Indeed, as noted earlier, if investment treaties only confer rights upon investors, the investment treaty regime should be considered as self-contained, thereby excluding the diplomatic protection rules of nationality. If, however, investment treaty rights are also owed on an interstate basis, a departure from these rules, including the dominant nationality test, can only be accepted to the extent that the state parties have clearly stated such an intention. ${ }^{98}$

The Archer Daniels and Corn Product tribunals famously addressed the question of who, the investor or the state, holds the substantive rights granted by investment

LaGrand); Avena and Other Mexican Nationals (Mexico v United States), ICJ Reports (2004) 12, para 40 (hereinafter: Avena).

95 ELSI (n 94) para 51.

96 LaGrand (n 94) para 77.

97 Avena (n 94) para 40.

98 TR Braun, 'Globalization-driven Innovation: The Investor as a Partial Subject in Public International Law - An Inquiry into the Nature and Limits of Investors Rights' (2014) 15 J World Invest Trade 73, 77. See also Z Douglas, The International Law of Investment Claims (2009) Cambridge University Press, 11 and Douglas, Hybrid Foundations (n 85) 192. 
treaties. Both cases involved claims against Mexico under the North American Free Trade Agreement (NAFTA). ${ }^{99}$

In Archer Daniels, the tribunal found that the substantive rights in Chapter 11 of NAFTA were conferred on an interstate basis, and that the investor only had a procedural right to enforce those rights. The tribunal distinguished between Part A of Chapter 11 of NAFTA, which contain various substantive obligations on the treaty parties, and Part B, which provides a procedural right for investors to bring claims:

$[\mathrm{T}]$ he proper interpretation of the NAFTA does not substantiate that investors have individual rights as alleged by the Claimants. Nor is the nature of investors' rights under Chapter Eleven comparable with the protections conferred by human rights treaties ... the fundamental difference between Chapter Eleven of the NAFTA and human rights treaties in this regard is, besides a procedural right of action under Section B, that Chapter Eleven does not provide individual substantive rights for investors, but rather complements the promotion and protection standards of the rules regarding the protection of aliens under customary international law ... The obligations under Section A remain inter-state. ${ }^{100}$

In Corn Products, the tribunal took a fundamentally different approach. It found that Chapter 11 of NAFTA confers both procedural and substantive rights to investors 'separate and distinct from those of the State of which they are nationals. ${ }^{101}$ In the tribunal's view, the direct access of investors to international arbitration under NAFTA meant that states no longer retained an interest in the investor's claim. The tribunal therefore considered the finding in Archer Daniels that investors merely enforce substantive rights owed to their home state as 'counterintuitive':

[W] hen a State claimed for a wrong done to its national it was in reality acting on behalf of that national, rather than asserting a right of its own. The pretense that it was asserting a claim of its own was necessary, because the State alone enjoyed access to international dispute settlement and claims machinery. However, there is no need to continue that fiction in a case in which the individual is vested with the right to bring claims of its own. ${ }^{102}$

In practice, therefore, there are two conflicting approaches regarding the nature of investment treaty rights. The first prescribes that investment treaty rights are owed to contracting parties, closely tracking the traditional approach of diplomatic protection as adopted in Mavrommatis. Investors own a procedural right to enforce the Case No ARB(AF)/04/05, Award, 21 November 2007 (hereinafter: Acher Daniels); Corn Products International, Inc $v$ United Mexican States, ICSID Case No ARB(AF)/04/01, Decision on Responsibility, 15 January 2008 (hereinafter: Corn Products).

100 Archer Daniels (n 99) paras 171-73.

101 Corn Products (n 99) paras 167-79.

102 ibid paras 169 and 173. 
rights of states (the derivative model). ${ }^{103}$ The second suggests that, by triggering arbitration proceedings under the treaty, the investor vindicates its own substantive rights rather than those of its national state (the direct right model). ${ }^{104}$

It is submitted here that neither the direct nor the derivative models reflect the reality behind the architecture of investment treaties and their allocation of rights. This contribution proposes an intermediate approach, one that seeks to integrate diplomatic protection and the investment treaty regime. It contends that, as has been already argued by some investment tribunals and scholars, investment treaty rights are jointly held by the investor and the home state in an interdependent manner (the 'integrative' model).

The task of determining who owns the substantive rights under investment treaties should start with the text of the treaty itself. In this respect, it should be first noted that most investment treaties do contain language expressly conferring substantive rights upon investors. The treaties do not, for instance, state that investors have a 'right' not to have their investment unlawfully expropriated. Instead, these instruments impose an obligation on host states not to expropriate the investor's investment except on certain conditions. ${ }^{105}$

With this in mind, it is difficult to say that a foreign investor entitled to pursue an investment treaty claim does not hold substantive rights under the treaty. After all, investors are directly compensated in the event that the host state fails to abide by treaty obligations. As Professor Roberts has explained 'the idea that investment treaties create substantive rights for treaty parties only seems hard to reconcile with investors' entitlement to direct damages awards, which is clearly more than procedural in nature'. ${ }^{106}$ However, the fact that investors have standing to bring arbitral claims does not mean that states do not hold substantive rights under investment treaties.

It should be recalled that, in addition to investor-state arbitration clauses, most investment treaties contain parallel state-to-state dispute settlement provisions,

103 For further authority in support of the derivative model see, eg, A Gourgourinis, 'Investors' Rights Qua Human Rights? Revisiting the 'Direct'/'Derivative' Rights Debate', in Malgosia Fitzmaurice and others (eds), The Interpretation and Application of the European Convention of Human Rights, Legal and Practice Implications (Martinus Nijhoff Publishers 2013), 182; The Loewen Group, Inc and Raymond L Loewen v United States of America, ICSID Case No ARB(AF)/98/3, Award, 26 June 2003, para 233.

104 For further authority in support of the direct model see, eg, Cargill Inc v United Mexican States, ICSID Case No ARB(AF)/05/2, Award, 18 September 2009; paras 402-28; Occidental Exploration and Production Co v Republic of Ecuador, English Court of Appeal, EWCA Civ 1116, No 222 Lloyd's Rep 707 (2005), para 20.

105 See, eg, Art V.1 of the Spain-Venzuela BIT. 'Las inversiones realizadas en el territorio de una Parte Contratante por inversores de la otra Parte Contratante no serán sometidas a nacionalizaciones, expropiaciones ... salvo que cualquiera de esas medidas se realice exclusivamente por razones de utilidad pública, conforme a las disposiciones legales, de manera no discriminatoria y con una compensación. al inversor o a su causahabiente de una indemnizacion pronta, adecuada y efectiva.' 'Investments made in the territory of one Contracting Party by investors of the other Contracting Party will not be subject to expropriation except for a public purpose, in accordance with the law, in a non-discriminatory manner, and on payment of prompt, adequate, and effective compensation.'

106 A Roberts, 'State-to-State Investment Treaty Arbitration: A Hybrid Theory of Interdependent Rights and Shared Interpretive Authority' (2015) 55(1) Harv Int L J, 39. 
which derive from almost identical provisions in FCN treaties. ${ }^{107}$ Article $\mathrm{X}$ of the Spain-Venezuela BIT provides a typical formulation:

\section{Cualquier controversia entre las Partes Contratantes referente a la interpretación o aplicación del presente Acuerdo será resuelta, hasta donde sea posible, por vía amistosa.}

2. Si la controversia no pudiera resolverse de ese modo en el plazo de seis meses desde el inicio de las negociaciones, será sometida, a petición de cualquiera de las dos Partes Contratantes, a un tribunal de arbitraje. ${ }^{108}$

The term application generally employed in state-to-state arbitration clauses implies that the home state has a parallel and autonomous right to bring a diplomatic protection claim on behalf of its investors. ${ }^{109}$ And this right is not precluded even if the same treaty also incorporates an investor-state arbitration provision. Indeed, investment treaties do not generally prioritize investor-state arbitration provisions over state-to-state arbitration provisions, nor do they exclude diplomatic protection claims. $^{110}$

However, some treaties, such as the ICSID Convention, prohibit the home state from exercising diplomatic protection after a dispute has been referred to investorstate arbitration. In this respect, it is important to note that the ICSID Convention also incorporates a state-to-state dispute resolution clause in Article 64, which provides that:

Any dispute arising between Contracting States concerning the interpretation or application of this Convention which is not settled by negotiation shall be referred to the International Court of Justice by the application of any party to such dispute, unless the States concerned agree to another method of settlement. $^{111}$

For its part, Article 27 of the ICSID Convention provides that:

No Contracting State shall give diplomatic protection, or bring an international claim, in respect of a dispute which one of its nationals and another Contracting State shall have consented to submit or shall have submitted to arbitration under this Convention, unless such other Contracting State shall have failed to abide by and comply with the award rendered in such dispute.

ELSI (n 94) paras 48-49.

108 Art X of the Spain-Venezuela BIT. '1. Any dispute between the Parties concerning the interpretation or application of this Treaty shall, to the extent possible, be resolved through amicable negotiations. 2. If the dispute is not resolved in this manner within six months from the initiation of the negotiations, it shall be submitted on the request of either Party to an arbitral tribunal.'

109 Roberts (n 106) 30; F Berman, 'The Relevance of the Law on Diplomatic Protection in Investment Arbitration' in F Ortino and others (eds), Investment Treaty Law: Current Issues II: Nationality and Investment Treaty Claims, Fair and Equitable Treatment in Investment Treaty Law (London British Institute of International and Comparative Law 2007), 72.

110 Roberts (n 106) 11.

111 See Art 64 of the ICSID Convention. 
Article 64, read in conjunction with article 27, reveals that the home state is prevented from exercising diplomatic protection only if both its national and the host state have previously consented to arbitration. The right to diplomatic protection will remain suspended pending the investor-state arbitration proceedings, and only revive if the host state fails to enforce the award. In other words, the ICSID Convention allows the home state to espouse a claim under Article 64 at any point before the investor has submitted a claim to arbitration. ${ }^{112}$

The above considerations suggest that the mere existence of an investor-state arbitration clause within a treaty does not automatically preclude diplomatic protection claims. In fact, having diplomatic protection as an alternative method to resolve investment disputes further enhances 'the object and purpose of increasing the efficacy of investment treaty obligations by increasing opportunities for enforcement by arbitration'. ${ }^{113}$ Thus, diplomatic protection may be considered as dispute resolution mechanism that exists in parallel to investor-state arbitration. ${ }^{114}$ This was the point posited in Diallo, ${ }^{115}$ where the ICJ saw the ICSID Convention and investment treaties in general as an alternative to diplomatic protection and not as one of its variations:

$[\mathrm{T}]$ he fact invoked by Guinea that various international agreements, such as agreements for the promotion and protection of foreign investments and the Washington Convention, have established special legal regimes governing investment protection ... is not sufficient to show that there has been a change in the customary rules of diplomatic protection; it could equally show the contrary. ${ }^{116}$

A corollary of the principle of allowing states to access international arbitration is that states also hold substantive treaty rights. As stated above, the investors' ability to pursue direct treaty claims is considered by many to have granted them substantive rights under investment treaties. The same conclusion can also be drawn with respect to states, since they are also entitled to bring treaty claims. It is precisely by virtue of the bond of nationality that the home state is protecting its own right to have international law (i.e. the treaty) respected in the treatment of its nationals.

Consistently with this view, Professor Roberts explains that the coexistence of investor-state and state-to-state arbitration provisions means that 'both home states

112 Roberts (n 106) 45.

113 ibid 47.

114 J Dugard, Fifth Report on Diplomatic Protection, A/CN.4/53820-21, 44, arguing that '[d]iplomatic protection, bilateral investment treaties and human rights treaties are all mechanisms designed to protect persons who have suffered injury as a result of an internationally wrongful act. They are meant to complement and support each other in the pursuit of this goal'. See also M Paparinskis, 'Investment Arbitration and the Law of Countermeasures' (2008) Br Yr Book Int L, 293 considering Dugard's statement as a 'persuasive policy rationale'; and Berman (n 109) arguing that '[i]f there is no arbitration instituted under the investment treaty regime, then certainly the scope for diplomatic protection remains untouched'.

115 Case Concerning Ahmadou Sadio Diallo (Republic of Guinea v Democratic Republic of Congo), ICJ Reports (2007) (hereinafter: Diallo). ibid para 90 . 
and investors ... have been granted substantive rights under investment treaties absent clear wording to the contrary. ${ }^{117}$ Moreover, she convincingly contends that these rights should be characterized as Avena-style 'interdependent' rights, rather than as 'independent' rights:

[I]n keeping with the hybrid nature of the investment treaty system, I argue that, while investment treaty rights have been granted to both investors and home states, this co-existence makes the rights qualified and shared, rather than absolute and exclusive, in nature. ${ }^{118}$

Accordingly, the substantive rights granted in investment treaties are 'concurrent and overlapping', so that the breach of an investment treaty provision will normally result in a violation of the rights of both the investor and the home state. ${ }^{19}$ The conferral of substantive treaty rights upon both investors and states necessarily indicates that the investment treaty system does not function in isolation from the diplomatic protection rules of nationality and the dominant nationality test. Put differently, if the intention of treaty parties had been to develop a special regime that totally departs from the general international law of state responsibility, investment treaties would not entitle states to enforce their own rights through diplomatic protection.

The above propositions find support in a decision rendered by an arbitral tribunal concerning a claim brought by Italy on behalf of several Italian investors under the Cuba-Italy BIT. ${ }^{120}$ In that case, Italy invoked the state-to-state arbitration clause contained in Article 10 of the treaty, which also incorporates an investor-state dispute resolution provision in Article 9. ${ }^{121}$ Italy argued that, in bringing the claim, it sought to enforce both its own substantive rights and those of its Italian investors who had invested in Cuba. ${ }^{122}$ More pointedly, Italy contended that this dual nature of the claim:

prend son origine dans l'institution de la protection diplomatique qui implique que le droit subjectif de l'Etat qui agit en protection diplomatique soit indissolublement connexe aux intérêts des personnes physiques et morales en faveur desquelles il agit. $^{123}$

118 ibid. See also, Robert Volterra, 'International Law Commission Articles on State Responsibility and Investor-State Arbitration: Do Investors Have Rights?' (2010) 25(1) ICSID Rev Foreign Invest L 218, 220 , arguing that ' $\mathrm{g}]$ enerally, one would have to say that the rights contained in an investment treaty are, at best, rights of investors that are shared with the $[\mathrm{s}]$ tate party and their $[\mathrm{s}]$ tate of nationality.' Roberts (n 106) 40.

Republic of Italy v Republic of Cuba, Ad Hoc Arbitral Tribunal, Interim Award, 15 March 2005 (hereinafter: Italy v Cuba, Interim Award); Republic of Italy v Republic of Cuba, Ad Hoc Arbitral Tribunal, Final Award, 15 June 2008 (hereinafter: Italy $v$ Cuba, Final Award). Italy $v$ Cuba, Interim Award (n 120) paras 24-25.

123 ibid para 25 . The origin of the claim 'was rooted in the very institution of diplomatic protection, which implies that the subjective right of the State which acts in diplomatic protection are indissolubly linked to the interests of the physical or juridical persons in whose behalf it is acting'. 
Cuba objected to Italy's claim, arguing that the existence of an investor-state arbitration provision in Article 9 of the BIT barred Italy from bringing a diplomatic protection claim. ${ }^{124}$ The tribunal rejected this objection and held that the investor's home state was entitled to exercise diplomatic protection at any point before its national submitted a claim or consented to arbitration under the treaty. ${ }^{125}$ In doing so, the tribunal drew an analogy to Article 27 of the ICSID Convention which, as explained above, allows a state to bring diplomatic protection claims only if the investor has not submitted the dispute to arbitration. ${ }^{126}$ The tribunal considered that diplomatic espousal under investment treaties was complementary to investor-state dispute settlement. ${ }^{127}$ It can therefore be said that by allowing Italy to pursue a claim on behalf of its nationals, the tribunal recognized that states also hold substantive rights under investment treaties. $^{128}$

Interestingly, Cuba also challenged the tribunal's jurisdiction on the ground that the Italian investors had failed to comply with the diplomatic protection rule of the exhaustion of local remedies. Italy argued that, in line with the majority position adopted in arbitral practice, investment treaties derogate from the customary law of diplomatic protection. ${ }^{129}$ However, the tribunal found that, unless otherwise agreed by the treaty parties, the customary law of diplomatic protection (including by implication its rules on nationality) should apply in a dispute initiated by a state under the BIT. ${ }^{130}$ The same rationale should be adopted when the investor brings a claim under an investment treaty. It seems illogical to displace the law of diplomatic protection in investor-state claims, as the tribunal did in Serafín, but to apply it to stateto-state claims. As a matter of consistency, states and investors should be subject to the same set of rules in a dispute arising out of an investment treaty.

Whatever view might be taken on this point, it is at least clear that investment treaties are not self-contained regimes. ${ }^{131}$ As Professor Crawford has stated, 'bilateral investment treaties in some sense institutionalise and reinforce (rather than replace)

ibid para 47.

ibid para 65 .

ibid.

ibid.

Roberts (n 106) 40. See also the recent award rendered in Urbaser $v$ Argengina where the tribunal found that, given the pararell existenice of a state-to-state arbitration provision in the Spain-Argentina BIT, the BIT should be understood as confering substanive rights upon both investors and states. In the words of the tribunal: '[i]t is certain and undisputed that the BIT's main and manifestly prevailing focus is on a number of standards of protection for the investors rights and interests, which are retained for the purpose of inducing and protecting foreign investments. Nevertheless, there is no provision stating that the investment's host State would not have any right under the BIT ... A further reading in simple terms confirms that such categorical understanding would be wrong.' Urbaser S.A. and Consorcio de Aguas Bilbao Bizkaia, Bilbao Biskaia Ur Partzuergoa v The Argentine Republic, ICSID Case No ARB/07/26, Award, 8 December 2016, paras 1183-84.

Italy $v$ Cuba, Interim Award (n 120) para 41.

ibid para 90.

Koskenniemi, 'Fragmentation of International Law: Difficulties Arising from the Diversification and Expansion of International Law', ILC, 58th Session, A/CN.4/L682 (2006), para 414 (hereinafter: the Fragmentation Report); J Crawford, Third Report on State Responsibility, UN Doc A/CN.4/507 (2000), para 157; Simma and Pulkowski (n 83) 146; C McLachlan, 'Investment Treaties and General International Law' (2008) 57 Int Comp L Quart 361, 366; Asian Agricultural Products Ltd (AAPL) v Republic of Sri Lanka, ICSID Case No ARB/87/3, Award, 27 June 1990, para 21 and Braun (n 98) 99. 
the system of diplomatic protection.' ${ }^{132}$ These instruments serve merely as an extension of the individual's options to seek redress for internationally wrongful acts, diplomatic protection being another remedy available to that effect. They are designed to enhance customary international law by providing a more efficient mechanism for the protection of alien property. All of this suggests that what has changed is the means by which investors resolve disputes in the international plane but not the law that applies to such disputes.

\section{THE INTEGRATION OF THE RULES OF DIPLOMATIC PROTECTION AND INTERNATIONAL INVESTMENT LAW}

The above analysis has demonstrated that the increased presence of individual investors in the realm of international dispute settlement is not sufficient to justify a departure from the customary law of diplomatic protection. While it is true that investment treaties grant investors ius standi to take action before international tribunals, this individual-state relation has not resulted in the creation of a new legal order. ${ }^{133}$ As argued above, international investment law draws from the same underlying principles that govern the customary law of diplomatic protection:

i. International investment law owes its very existence to the elementary principle of customary law that states are entitled to protect their nationals, when injured by acts committed by other states contrary to international law.

ii. The entitlement to diplomatic protection and the operation of investment treaties are both dependent upon the link of nationality between the individual and the home state.

iii. Investment treaties also contain procedural mechanisms that allow state parties to enforce their own rights and those of their nationals by means of diplomatic protection.

A more realistic approach is therefore to consider that the law of diplomatic protection coexists in parallel with international investment law. ${ }^{134}$ This means that, as a part of customary international law, the diplomatic protection rules of nationality, including the dominant nationality test, are applicable in investment treaty arbitration unless otherwise agreed by the contracting states. ${ }^{135}$ In the words of Joost Pauwelyn, " $[\mathrm{i}] \mathrm{t}$ is for the party claiming that a treaty has "contracted out" of general

132 James Crawford, 'The ILC's Articles on Responsibility of States for Internationally Wrongful Acts: A Retrospect' (2002) 96(4) Am J Int L 874, 888. See Diallo (n 115) para 90.

133 GI Hernandez, 'The Interaction Between Investment Law and the Law of Armed Conflict in the Interpretation of Full Protection and Security Clauses', in F Baetens (ed), Investment Law within International Law, Integrationist Perspectives (Cambridge University Press 2013), 46.

134 T Gazzini, 'The Role of Customary International Law in the field of Foreign Investment' (2007) $8 \mathrm{~J}$ World Invest Trade 691, 697-98; P Dumberry, 'Are BITs Representing the 'New' Customary International Law in International Investment Law’ (2010) 28 Penn State Int L Rev 675, 676.

135 Simma and Pulkowski (n 83) 146-47; the Fragmentation Report (n 131) paras 184-85; ELSI (n 94) para 50; Military and Paramilitary Activities in and against Nicaragua (Nicaragua $v$ United States of America), ICJ Reports (1986), para 274; Gabcikovo-Nagymaros Project (Hungary v Slovakia), ICJ Reports (1997), para 132. These authorities support the proposition that the general international law 
international law to prove it. ${ }^{136}$ Such reasoning is even more compelling where an investment treaty does not address a particular issue, in which case customary international law will be introduced as a lacuna-filling instrument:

[E]ven in fields where there are widely accepted 'codification' conventions, the rules of customary international law continue to govern questions not regulated by the conventions and continue to apply in relations with and between non-parties. Rules of customary international law may also fill possible lacunae in treaties, and assist in their interpretation. ${ }^{137}$

More pointedly, in Société Générale v Dominican Republic, the tribunal found that:

[I]t is necessary to keep in mind that while it is true that investment law has meant in some respects a departure from the law governing diplomatic protection and the traditional law of international claims, this is correct largely to the extent that applicable treaties and conventions have so established by providing rules different from those of diplomatic protection ... the rules governing issues not addressed by the specific language of the treaty may sometimes be provided by the law of diplomatic protection, which apply as customary international law, and thus, provides for a residual role for at least some aspects of the law of diplomatic protection. ${ }^{138}$

This view finds support in Article 17 of the ILC Draft Articles on Diplomatic protection, relied upon by the tribunal in Serafín. As noted earlier, this provision makes it clear that the Draft Articles do not apply 'to the extent that' they are inconsistent with the provisions of an investment treaty. However, to the extent that the Draft Articles remain consistent with the respective investment treaty, they continue to apply. It is argued here that a rule contained in a Draft Article, such as the rule of dominant and effective nationality, ${ }^{139}$ would not be inconsistent with the treaty unless the state parties have expressly contracted out of that rule. Put differently, if the treaty fails to regulate the issue of dual nationality, Article 17 would render the rule of dominant and effective nationality applicable to investor-state arbitration. ${ }^{140}$

of state responsibility, which includes the law of diplomatic protection, is applicable whenever the special regime contains not explicit derogation.

136 J Pauwelyn, Conflict of Norms in Public International Law: How WTO Law Relates to Other Rules of International Law (2003) Cambridge University Press, 213

137 M Wood, ILC, 'First Report on Formation and Evidence of Customary International Law', ILC, 68th Session, A/CN.4/663 (2013), 15. See also J d'Aspremont, 'International Customary Investment Law: Story of a Paradox' in T Gazzini and ED Brabandere (eds), International Investment Law, the Sources of Rights and Obligations (2012) Martinus Nijhoff, 27. A Roberts, 'Triangular Treaties: The Extent and Limits of Investment Treaty Rights' (2015) 56(2) Harv Int L J, 363.

138 Société Générale v Dominican Republic, LCIA Case No UN 7927, Award on Preliminary Objections to Jurisdiction, September 19, 2008, para 108.

139 See Draft Art 7.

140 Douglas (n 98) 327, arguing that '[it] is evident that the ILC has taken the view that the special rules for the nationality of claims in investment treaties do not displace or are not otherwise inconsistent with the rules of general international law for the admissibility of diplomatic protection claims'. 
This approach is also consistent with Article 31(3)(c) of the VCLT. As described above, this provision states that, when interpreting treaty provisions, an arbitral tribunal is bound to consider 'relevant rules of international law applicable in the relations between the parties'. In keeping with the integration of international investment law and the customary law of diplomatic protection, Professor McLachlan argues that Article $31(3)(\mathrm{c})$ contains a requirement 'with both positive and negative aspects:

a. Positively, that the parties are to have taken to refer to general principles of international law for all questions which [the treaty] does not itself resolve in express terms or in a different way; and

b. Negatively, that, in entering into treaty obligations, the parties intend not to act inconsistently with generally recognised principles of international law or with previous treaty obligations towards third states' ${ }^{141}$

Drawing from the foregoing submissions, the conclusion seems to be that treaty provisions should not apply in isolation from the diplomatic protection rules of nationality. In other words, the absence of a provision in an investment treaty regulating dual nationality should not be interpreted as a waiver of the customary rule of dominant and effective nationality.

There is authority in support of the proposition that the often-sparse wording of nationality requirements in investment treaties should not prevent an arbitral tribunal from applying the customary rule of dominant and effective nationality when ascertaining its jurisdiction ratione personae. For instance, in the survey of investment treaties conducted by Dolzer and Stevens, the authors found that, by and large, investment treaties fail to address questions of dual nationality, leading them to conclude that 'general principles of international law would apply, according to which the "effective" nationality of the individual would govern.. ${ }^{142}$

Similarly, Krishan argues that the dominant and effective nationality test 'should only apply in multiple nationality cases where the effective link is with the defendant State. Its operation against the Claimant should only apply when the Respondent State is one of the multiple nations involved'. ${ }^{143}$

Professor McLachlan also supports this position stating that when an investment treaty fails to regulate the standing of dual nationals, a tribunal may consider applying the diplomatic protection rule of dominant and effective nationality to fill the gap in the treaty. ${ }^{144}$

In Feldman $v$ Mexico, a case brought under the NAFTA, the tribunal confirmed that the rule of dominant and effective nationality applies in cases where the investor

McLachlan (n 131) 373.

Dolzer and Stevens (n 54) 34.

D Krishan, 'Nationality of Physical Persons' in Ortino (n 109) 66.

C McLachlan and others, International Investment Arbitration, Substantive Principles (2017) Oxford University Press, 185. See also Douglas (n 98) 321-23; M Paparinskis, 'Investment Treaty Interpretation and Customary Investment Law Preliminary Remarks' in C Browns and K Miles (eds), Evolution in Investment Treaty Law and Arbitration (Cambridge University Press 2011), 72; C McLachlan, 'The Principle of Systemic Integration and Article 31(3)(c) of the Vienna Convention' (2005) 54(2) Int Comp L Quart 279, 293-94 and ND Rubins and others, Investor-State Arbitration (2008) Oxford University Press, 304. 
holds dual nationality. This case involved an American national, Mr Feldman, who had resided and worked in Mexico for the previous 27 years. Pursuant to Article 201 of NAFTA, the nationality of an investor could either be determined by the state of citizenship or that of permanent residence. Relying on this provision, Mexico argued that, as a permanent resident of Mexico, Mr Feldman should be regarded as having Mexican nationality, and therefore, in the present case, an instance of dual nationality arose which called for the determination of the dominant and effective one. The tribunal rejected Mexico's argument, holding that residency was not the relevant criterion for nationality:

$[G]$ iven the legal and the factual background of this case, the Tribunal deems it appropriate to recall that, under general international law, citizenship rather than residence or any other geographic affiliation is the main connecting factor between a state and an individual. Residence, even permanent or otherwise authorized or officially certified residence, only fulfills a subsidiary function which, as a matter of principle, does not amount to, or compete with, citizenship. In particular, in matters of standing in international adjudication or arbitration or other form of diplomatic protection, citizenship rather than residence is considered to deliver, subject to specific rules, the relevant connection. ${ }^{145}$

The tribunal then noted that the customary rule of dominant and effective nationality requires that the investor be a citizen (or national) of both contracting parties:

[D] ual nationality problems, including the search of the 'dominant or effective nationality', require the existence of a double citizenship, connecting the same individual to two states with the legal bond of citizenship in the generally accepted meaning of the term. For the sake of avoiding misunderstandings, the Tribunal notes that, with respect to the issues discussed here, no distinction between citizenship and nationality is either relevant or followed in this interim decision. $^{146}$

Accordingly, given that Mr Feldman was not a Mexican national for the purposes of NAFTA, it was not necessary to apply the dominant and effective nationality test. It can therefore be said that the Feldman tribunal did not discard customary international law since it considered that the dominant and effective nationality becomes relevant when the investor also holds the nationality of the host state.

As noted earlier, in line with the view expressed by these authorities, the Iran/US Claims Tribunal found that the Algiers Accords were consistent with the customary rule of dominant and effective nationality. Like investment treaties, the Algiers Accords were created for the purpose of resolving claims of private individuals against states that arise out of measures affecting property rights. Despite this, the 
tribunal looked beyond the four corners of the agreements and applied the customary rule of dominant and effective nationality.

Clearly, the tribunal's decision in Serafin to apply the nationality requirements of the BIT in isolation from customary international law sits poorly with these findings.

First, nothing in the Spain-Venezuela BIT indicates that the states party had opted out of the customary rule of dominant and effective nationality. The terms of the treaty were broadly worded and only referred to natural persons holding the nationality of the home state.

Second, the tribunal disregarded the fact that the Spain-Venezuela BIT expressly requires that any dispute arising out of the treaty be resolved through the application of 'rules and principles of general international law', which include the dominant and effective nationality test.

Third, the tribunal overlooked that the Spain-Venezuela BIT contains a state-tostate arbitration provision in Article $\mathrm{X}$ allowing states to bring diplomatic protection claims on behalf of their nationals. This provision, together with the BIT nationality requirement, show that the contacting parties intended to create a legal instrument that integrates customary international law within its scope of application.

In the author's view, therefore, the tribunal erred in finding that the absence of a treaty provision on dual nationality implied a waiver of the dominant and effective nationality test. Given that the investors in that case maintained more substantive connections with Venezuela, the tribunal should have declined its jurisdiction under the BIT.

In reality, the dispute currently ongoing in Serafín is between two Venezuelan nationals and the Venezuelan Government. However, as Professor Weil succinctly stated in his dissent in Tokios Tokelés, investor-state dispute settlement mechanisms are 'meant for international investment disputes, that is to say, for disputes between States and foreign investors'. ${ }^{147}$ It is hard to see how individuals who hold the nationality of the host state and have developed a long-standing relationship with that state can be considered as 'foreign' investors. To put it bluntly, by allowing the investors to pursue their claims against Venezuela, the tribunal failed to preserve the international element that must be present in every investment claim.

\section{CONCLUSIONS}

Dual nationals should not be allowed to claim against their own state simply on the ground that there is no treaty provision prohibiting them from doing so. In cases where an investment treaty fails to regulate the standing of dual nationals, an arbitral tribunal should apply the customary rule of dominant nationality and uphold jurisdiction only if the dominant nationality of the individual is that of the home state.

As a result of the decision in Serafin, investors with dual nationality have begun to sue their own states under investment treaties, and it is reasonable to expect that such claims will continue to arise. This decision can also be considered as creating an incentive for investors with one nationality to 'internationalise' their claims through the acquisition of a second nationality to benefit from the investment system. With 
this in mind, states may wish to consider addressing, or amending, the issue of dual nationality explicitly in future and present treaties to prevent potential abuse, as Russia has done.

In the meantime, it remains to be seen whether the current (and future) arbitral tribunals deciding claims by dual nationals will follow the restrictive approach adopted in Serafin or if, on the contrary, they will apply the limitations imposed by the customary law of diplomatic protection to prevent treaty abuse by investors who are not (truly) foreign. 